\title{
Tourism and rural community development in Namibia: policy issues review
}

\author{
ERLING KAVITA AND JARKKO SAARINEN
}

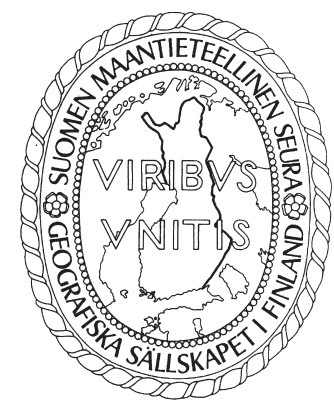

Kavita, Erling \& Jarkko Saarinen (2016). Tourism and rural community development in Namibia: policy issues review. Fennia 194: 1, 79-88. ISSN 1798-5617.

During the past decades, the tourism sector has become an increasing important issue for governments and regional agencies searching for socio-economic development. Especially in the Global South the increasing tourism demand has been seen highly beneficial as evolving tourism can create direct and indirect income and employment effects to the host regions and previously marginalised communities, with potential to aid with the poverty reduction targets. This research note reviews the existing policy and planning frameworks in relation to tourism and rural development in Namibia. Especially the policy aims towards rural community development are overviewed with focus on Community-Based Tourism (CBT) initiatives. The research note involves a retrospective review of tourism policies and rural local development initiatives in Namibia where the Ministry of Environment and Tourism (MET) initiated a community-based tourism policy. The policy emphasises structures and processes helping local communities to benefit from the tourism sector, and the active and coordinating involvement of communities, especially, is expected to ensure that the benefits of tourism trickle down to the local level where tourist activities take place. However, it is noted that in addition to public policy-makers also other tourism developers and private business environment in Namibia need to recognize the full potential of rural tourism development in order to meet the created politically driven promises at the policy level. In this respect, a national tourism policy could provide an enabling framework, integrating the tourism sector's development aims to rural and community development needs in future. In addition, there is a need to coordinate a comprehensive vision of what type of rural tourism development or tourism in rural environments holds the most potential to benefit both local communities and the mainstream sector.

Keywords: tourism, community-based tourism, rural development, conservancies, Namibia

Erling Kavita, Department of Hospitality and Tourism, Polytechnic of Namibia, Private Bag 13388 Windhoek, Namibia, and Tourism Management Division, Department of Marketing Management, University of Pretoria, Private bag X2O Hatfield, Pretoria 0028, South Africa.E-mail: ekavita@polytechnic.edu.na

Jarkko Saarinen, Department of Geography, PO Box 3000, 90014-University of Oulu, Finland, and Tourism Management Division, Department of Marketing Management, University of Pretoria, Private bag X20 Hatfield, Pretoria 0028, South Africa.. E-mail: jarkko.saarinen@oulu.fi

\section{Introduction}

During the past decades, tourism has become an increasingly important sector for governments and regions searching for socio-economic development and employment creation. Especially in the Global South the growing tourism demand is seen highly beneficial as evolving tourism can create direct and indirect income and employment effects to the host regions, which have further emphasised community involvement and community-based tourism initiatives in many countries (Sinclair \& Stabler 1997; Binns \& Nel 1999; Saarinen \& Rogerson 2014), including Namibia (Novelli \& 
Gebhardt 2007; Jänis 2009; Lapeyre 2011). Tourism services and facilities can also improve the general level of infrastructure of a region which benefits local population by providing new, or maintaining the old, services and infrastructure (see Brown \& Hall 2008). Tourism businesses generate tax revenues, including revenues from employees. In addition, tourism promotion creates positive destination images attracting not only tourists but also businesses, capital investments and new skilful employees, like the so called creatives (see Florida 2002; Hall 2008).

In relation to the Global South contexts, Sinclair and Stabler (1997) have suggested that increasing tourist demand has a significant impact on developing countries' economies. Therefore, in many governmental strategies, the Global South tourism has emerged as a driver for development that goes beyond economic issues and the sector is also used for promoting economic diversification and strengthening national economies (UNCTAD 2010). However, Sinclair (1998) has further indicated that the economic aspects of tourism should be placed in an equation consisting of both the advantages and disadvantages of tourism development. Therefore, the economic costs, such as inflation, leakages, land use changes, security needs, crime and the increase of domestic prices should be considered. In addition, tourism creates cultural, social and environmental changes and impacts while issues such as opportunity costs are rarely discussed in relation to tourism development and planning strategies.

All these aspects may have serious direct or indirect socio-economic implications, and, thus, eventually create costs for the host regions. In order to manage the costs and benefits of tourism development, many countries and regions have created strategies that aim to highlight the social responsibility of the sector and its benefit by sharing capacity at local and regional levels. This has sparked various participatory planning and community-based tourism and natural resource management strategies, programmes and projects which emphasise the sustainability of the businesses and local participation needs (Aref 2011). By involving local communities, the benefits of tourism are expected to trickle-down to a local level where the tourist activities and impacts actually take place (see Saarinen 2011).

This review paper aims to discuss and review the policy issues relating to the development of tourism in the Namibian context. Especially the policy aims towards rural community development are overviewed with focus on CommunityBased Tourism (CBT) initiatives. CBT can be defined as an activity which "through increased intensities or participation, can provide widespread economic and other benefits and decision-making power to communities" (Tribe 2006: 365). As a policy tool, the CBT aims to ensure that members of the local communities hold a high degree of control over tourism activities and can receive a significant portion of the benefits (see Novelli \& Gebhardt 2007; Lapeyre 2011). Recently, the ethical aspects of tourism consumption and production have been emphasised referring to development processes where tourism would be used as a tool for reducing poverty, ensuring environmental sustainability, developing a global partnership and empowering previously neglected communities and social groups (Scheyvens 2002, 2011), as it was also highlighted in the UN Millennium Development Goals (Saarinen \& Rogerson 2014). In human geographical approaches to regional development and tourism, these issues of ethics, inequalities and sustainability, for example, are highly relevant both academically and societally (see Binns \& Nel 1999; Gibson 2010; Saarinen 2014). Especially in the context of tourism and development, the local participation, tourism awareness, the devolution of power and benefit sharing have been highlighted with an emphasis on community-based tourism initiatives, which are highly relevant in the Namibian and wider southern African development policy contexts (Rogerson 2006; Jänis 2009; Saarinen 2011). Based on this relevance the paper uses Namibian community-based related policy documents by analysing their emphasised key aims which guide community participation in tourism development.

\section{Tourism development in Namibia}

After the independence in 1990 the government of Namibia embarked on a new programme of economic development, which indicated that tourism could significantly contribute to the overall development of the country in the future (Weaver \& Elliot 1996). Consequently, the Cabinet declared tourism a priority sector in 1991 (Jenkins 2000). The main tourism products of the country are based on wildlife and wilderness experiences and arid landscapes. In addition, the ethnic groups and rural populations are visibly utilised in the tourism pro- 
motion but their actual role is sometimes marginalised (see Novelli \& Gebhardt 2007; Saarinen \& Niskala 2009; Lapeyre 2011; Ndlovu et al. 2011).

At a general level, the growth of tourism in $\mathrm{Na}$ mibia has been positive. In the tourism peak year 2007 , the sector directly contributed $16.3 \%$ to GDP and 73,000 jobs representing $17.7 \%$ of total employment (WTTC 2006). Indeed, prior to the start of global financial crises in 2008 the Namibian tourism sector registered a good growth in the tourist arrivals, but the development has been relatively moderate since 2008 (Fig. 1). Regionally, the tourism development is highly polarised and concentrates on the capital city of Windhoek, coastal towns and resort environments, such as Swakopmund and Walvis Bay, and Etosha National Park.

Although tourist activities are concentrated on certain hot spots, tourism in rural communal areas and particularly community involvement in tourism were actively promoted from the start of the new economic development thinking in the 1990s, both by the government and Non-Governmental Organisations (NGOs) (Ashley 2000). Currently the role of communities and CBT is highlighted in the national development policies with an aim to use the tourism sector as a medium for achieving economic and social goals at various levels (see MET 2007).

Since the independence, Namibia has managed to distinguish itself as a country with an enabling environment for development in general and for a CBT enabling environment in particular. Key ena- blers include peace and political stability, good governance, transport, developed information and communication technologies (ICTs) infrastructure, sound economic policies and community-based natural resource management (Jänis 2009). Namibia also has good prospects for accelerating growth. However, despite an enabling environment and good growth prospects, the country has consistently experienced difficulties in meeting its development goals and performance targets. Poverty is endemic with close to $35 \%$ of the population living on less than one US\$ per day while nearly $56 \%$ live on less than two US\$ per day ( $\mathrm{Na}-$ her 2006). Income inequalities are among the highest in the world (a Gini coefficient of 0.70) (WEF 2001) and Namibia's low-middle income status alongside per capita income of US\$2,156 indicates severe inequalities (Marope 2005). The national average unemployment rate is about $52 \%$. Unemployment is highest among the unskilled and youth (Novelli \& Gebhardt 2007).

To better respond to these challenges, the government has aimed to reform the national development strategy. The reform agenda is encapsulated in a long-term vision for national development - Vision 2030. A key aspiration of Vision 2030 is to rapidly transform Namibia into a high-income and more equitable knowledge economy (Scholz 2009). The broad goals of the reform are to accelerate economic growth and social development, eradicate poverty and social inequality, reduce un-
Fig. 1. Number of tourist arrivals in $\mathrm{Na}$ mibia (adapted from NTB 2012: 14).

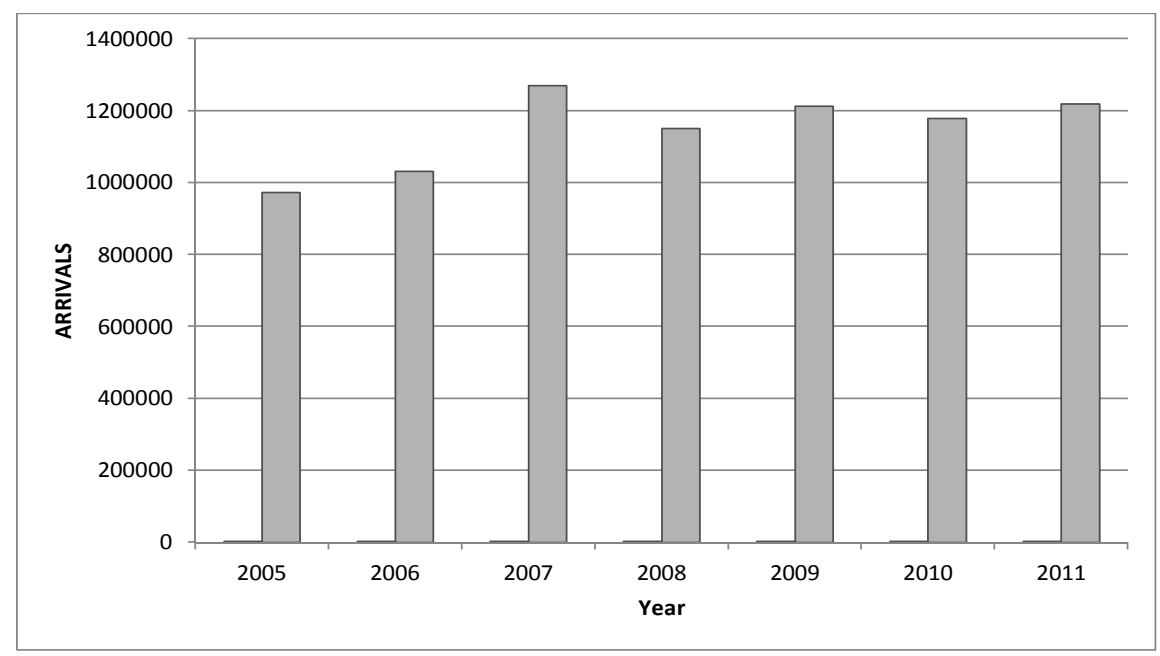


employment, especially youth unemployment, and curb the spread of HIV/AIDS.

As a result, the Namibian government regarded tourism as a sector making a vital contribution to poverty alleviation. The National Poverty Strategy states that over the next decade, no other segment of the economy has as much potential to create jobs and generate income for Namibia's rural communities than the tourism sector. Like many other developing countries, Namibia's tourism has been viewed from four perspectives by Cole (2006: 630): a) economists generally see tourism as a route to macro-economic growth and particularly a means of generating foreign exchange; b) for the private sector tourism is a commercial activity, so the main concerns are product development, competitiveness and commercial returns; c) many conservationists now see tourism as a form of sustainable use of wild resources and as a way to enhance incentives for conservation; and d) for rural people and the development NGOs that support them, tourism is one component of rural development.

The interests of the Namibian government embrace all four perspectives, with central ministries focusing on macro-economic objectives, the conservation and environment directorates on conservation incentives and the tourism directorate on the development of the sector in conjunction with the private sector.

Ashley (2000: 8) notes a growing interest in tourism contribution to local rural development, which is now seen as a key element in each of the above perspectives. Several NGOs working in conservation and development include tourism development in their work with communities (Dixey 2008; Jones \& Weaver 2009; Owen-Smith 2010). Furthermore, the importance of tourism is clearly acknowledged by the Namibian government in the National Development Plan (NDP) and in the National Poverty Reduction Action Programme (NPRAP) 2001-2005. In the latter, Action 26 assigns the Ministry of Environment and Tourism (MET) the role of assisting rural and disadvantaged communities to setup CBT projects, such as business and joint-ventures, to facilitate training and enable capacity building. Furthermore, on the basis of the general premises of CBT, Namibia has initiated a CBT policy, which aims to explore ways in which local communities can benefit from the tourism sector (NACSO 2007; Saarinen et al. 2009). The policy has strong links with the Namibian Community-Based Natural Resource Management (CBNRM) programme and Communal Con- servancy System (CCS) (Long 2004) that have served the development of CBT in the country. Conservancies are based on communal lands that are in general managed by communities aiming to use the natural resources of these areas in conservation and development purposes. Thus, conservancies take responsibility for the natural resources, especially wildlife, in a sustainable way, which often involves the development of tourist activities (NACSO 2007).

\section{Community-based tourism in Namibia}

\section{Historical background}

Although rural communities inhabiting communal lands had some usufruct rights, the South African government retained ultimate control over land users before independence (Long 2004). In particular, the colonial State kept full decision-making power over commercial and hunting rights in communal lands and captured most revenues from photographic tourism and hunting activities. By contrast, in 1975, commercial farmers on private lands gained additional ownership rights over certain natural resources, especially game species, and thus could exclusively use available resources and fully benefit from both consumptive (hunting) and non-consumptive (photographic) tourism (see also Owen-Smith 2010).

At the independence, the new Namibian government inherited a highly skewed land distribution (Massyn 2007). In that period, freehold lands comprised $44 \%$, protected areas $15 \%$, and communal areas, where most of the people lived, $41 \%$ of the lands (Fuller et al. 2006). Consequently, the majority of rural inhabitants stayed in a limited and overcrowded portion of arid land and natural resources were depleted, thereby threatening environmental sustainability. Currently, the pattern of poverty in Namibia mirrors the unequal distribution of land. Furthermore, the uneven allocation of land and resources commonly led to underdevelopment and poverty among rural communities (Ashley \& Maxwell 2001). In this context, redistributing land through land reform and devolving rights over resources became the highest priority of government to redress past inequalities and to reconcile conservation and development.

Hence, the 1995 Policy on Wildlife Management, Utilization, and Tourism in Communal Are- 
as clearly intended to "amend the Nature Conservation Ordinance of 1975 so that the same principles that govern right to wildlife utilization on commercial land are extended to communal land" (Lapeyre 2010: 758). The policy stated that 1) the right to utilise and benefit from wildlife on communal land should be devolved to a rural community that forms a conservancy; 2) each conservancy should have the right to utilise wildlife within the boundaries of the conservancy to the benefit of the community, once quotas have been set; 3 ) the conservancy should be able to enter into a business arrangement with private companies; and 4) the conservancy would also have the right to establish tourism facilities (see Massyn 2007). In order to harness the potential of these policy aims for rural community development, another tourismfocused framework was needed: the communitybased tourism policy.

\section{Community-based tourism policy}

In the report commissioned by the Overseas Development Institute (ODI), Ashley and Haysom (2008) observed that the Ministry of Environment and Tourism (MET)'s vision of CBT is in many ways different from what is found in the literature. MET is interested in a large scale, ambitious and implementable approach to rural tourism development. For this reason, CBT in Namibia has been conceptualised in its widest sense meaning "tourism that occurs at a local level and seeks to benefit local communities in its impact" (Ashley 2000: 16).

There is a broad acceptance of tourism as a strategy for rural development in Namibia. Especially the CBT approach and its adoption by the government and powerful NGOs have highlighted the profile of tourism in regional development in rural areas and communities. In this respect, major international donors have assisted in building community tourism, organisation and programme development (Lapeyre 2011). Within this highly supportive context, CBT projects have flourished in Namibia. In particular, three distinct forms of CBT were promoted and supported through donor funded programmes: 1) Community-Based Tourism Enterprises (CBTEs) owned and managed by a community as a group; 2) indigenous enterprises, owned and managed by individuals coming from a rural community; and 3) community-private sector joint ventures where a rural community is commercially partnering with a private operator to own and run a tourism facility.
These programmes and approaches are based on a legislative change in 1994 that made possible for communities in rural communal areas to acquire limited common property rights to manage and use their wildlife resources (Barnes \& Novelli 2008). Communities were enabled to register conservancies through which they could take on rights and manage and use wildlife resources, with the assistance of NGOs and the government. A conservancy is a territorial unit where resource management and utilisation activities are undertaken by an organized group of people. To register as a conservancy the following criteria should be in place: a defined membership; elected committee members; agreed boundaries; a constitution including resource management strategy and a plan for equitable distribution of benefits (Libanda \& Blignaut 2007; NACSO 2007). With a long term support from donors and government to develop Namibia's CBT programme (Table 1), communities in rural parts of the country have established some 50 conservancies on large portions of communal lands.

Namibia's conservancy programme is regarded as one of the most innovative and effective community conservation and development initiatives in the world (Lapeyre 2011). This programme, which had its beginning in the early 1980s, has evolved through a number of phases, growing from an embryonic community game guard project in northwest Namibia into a full blown, national rights -based communal conservancy movement, covering more than $20 \%$ of Namibia's surface.

On the basis of the creation of legal ground for conservancies and the positive prospects of CBT, the Ministry of Environment and Tourism (see MET 2007) initiated the CBT policy, which aims to explore ways that local communities can benefit from the tourism sector (NACSO 2007; Saarinen 2010). The policy has strong links to the Namibian Community-Based Natural Resource Management (CBNRM) programme and Communal Conservancy System (CCS) (Long 2004). The key issues in the Namibian CBT policy are related to the previously raised questions of participation and empowerment: "how to integrate local communities in tourism planning and how to ensure a sufficient level of power and control in the decision-making process concerning the use of natural and cultural resources in tourism" (Lapeyre 2011: 307). Clearly, the legal framework aims at involving rural communities in tourism at three levels. First, communities must be involved in the design and planning of tourism on their lands. Second, communities must 
Table 1. Major steps in the development of the Namibian Community-Based Tourism (CBT) (adapted from Jones \& Weaver (2009: 145).

1996 Parliament approves the new conservancy legislation.

1998 The first communal area conservancy is gazetted on 16 February. Three more communal area conservancies are gazetted by mid-year. The national Community-Based Natural Resource Management (CBNRM) coordinating body is launched to promote synergy and lesson sharing in the development and support of communal area conservancies. President San Nujoma officially launched the Namibian Communal Area Conservancy Programme in September. The innovative nature of the programme is recognized by WWF's Gift to The Earth' award.

1999 The second phase of LIFE Programme begins, to run for further five years.

2000 The Namibia Association of CBNRM Support Organization (NACSO) is constituted in March (the association was previously known as the CBNRM Association of Namibia).

200431 communal area conservancies are registered and more than 50 others are in the process of being formed. The national programme is supported by three major donors (LIFE Plus, the Integrated Community-Based Ecosystem Management (ICEMA) project funded by the Global Environment Facility and IRDNC activities in Kunene and Caprivi regions funded by WWF, UK).

200750 communal area conservancies are registered and 20-30 are under development.

2008 The LIFE project ends in April, but the CBNRM programme continues with the support of government and other donors.

2008- USA Government Millennium Challenge Corporation largely invested in CBT: an estimated US\$ 85 million.

take part in the operation and management of tourism activities, either through community facilities or through commercial partnerships with the private sector. Finally, communities must capture benefits (revenues) from the operation of tourism activities on their land (see Ashley 2000).

\section{Discussion: towards a National Tourism Policy in Namibia?}

Although the principal benefits of CBT are widely recognised (Hall 2008; Lapeyre 2010; Saarinen 2011), the actual socio-economic benefits to the community can be difficult to achieve. Blackstock (2005), for example, calls CBT as naive and unrealistic due to its focus in practice on sector development compared to community empowerment. In addition, she states that CBT often ignores the internal dynamics of communities and the external barriers, such as inequality between developers and local community members that affects the degree of local control. Therefore, despite presenting an alternative response to traditional forms of tourism development, there are several elements that may explain the lack of significant economic impact from CBT in Namibia.

First, rural communities and supporting NGOs have limited capacity in tourism project management. Many local communities have low managerial capacity to deal with management issues (flexible decision making, accounting, pricing, punctuality, stock taking, forward booking, etc.) and business issues (advertising and distribution networks) (Simpson 2007). In Namibia, Murphy (2004) also provides further evidence that communal management of Community-Based Tourism Enterprises (CBTEs) is time consuming and often in contradiction with the sector's standard time scale. In addition, development agencies and NGOs often lack sector knowledge and are "notoriously illequipped to deal with product quality requirements and the promotion of tourism initiatives" (Simpson 2007: 187). Also in Namibia, the Namibia Community-Based Tourism Association (NACOBTA) and other implementing field-based NGOs are staffed with community-focused workers with little or no knowledge of the international and Namibian tourism sector. Thus, they may have limited capacity and lack an appropriate orientation and the financial business skills needed in 
tourism (Hirsch 1978; Rapley 2002). In this context, while necessary and highly laudable, NGOs' support to CBT fails to efficiently resolve such issues as the limited capacity within a single particular community. Indeed, most NGOs and donors involved in the development of CBT in Namibia are specialised and focused on biodiversity conservation and rural development programmes rather than on tourism as a business, management and marketing.

Second, CBT is only marginally integrated in the very competitive tourism value chain (Lapeyre 2011). Communities are new entrants in the tourism sector with little or no previous experience (Kiss 2004; Simpson 2007). As a result, most communities have limited knowledge about the tourism sector and limited skills in tourism management and operation (Tosun 2000). Despite valuable training efforts by the NACOBTA, communities in Namibia still have poor awareness about, and knowledge of, the tourism market.

Third, we consider that there is further need for a broader policy framework for tourism development better integrating business perspectives with community needs. While the CBT policy is in place, it may not guide a wider tourism development if it is not integrated into the mainstream tourism policies. The actual National Tourism Policy that focuses on the mainstream tourism sector has been under development since 1995. The first comprehensive draft was circulated to stakeholders in 2005 and the most recent draft was completed in 2007 (Jänis 2009). Both drafts state that the policy aims to provide long-term National Development Plans 2001/2-2005/6 and 2007/82011/12 (see NTB 2012). However, the earlier draft from 2005 is more explicit about how tourism can contribute to the development objectives, while the 2007 draft is more focused on tourism as a viable and competitive economic sector and it has less emphasis on the role of tourism in national development priorities. As the 2007 draft was prepared by an external consultant provided by the European Union (EU), it can be questioned whether this change in emphasis reflects the views of the Namibian government or the consultant. What is clear is the difference between the two versions and how the role of tourism is placed in the national and regional development contexts. The 2005 draft highlights the importance of preparing a national tourism strategy and action plan to articulate the practical implementation of the policy (MET 2007). However, the 2007 draft pro- poses a national tourism growth strategy that implies a clear emphasis on a growth-focused neoliberal approach as adopted by the Namibian government (Jauch 2001; MET 2007). Furthermore, the 2005 draft discusses the challenges and opportunities of CBT as a means of distributing the benefits of tourism, whereas the 2007 draft omits CBT and mentions only the need for partnerships between the private sector and local communities in order to distribute the benefits (Jänis 2009). In general, tourism in Namibia is considered to have major potential for employment and income generation in the country, and the role of communitybased tourism and community-based natural resource management with tourism development elements in particular are highlighted by national policies (Saarinen 2010).

\section{Conclusions}

Tourism is increasingly used as a mechanism for achieving different societal and economic goals in Namibia. In general, tourism is considered having major potential for employment and income generation. Especially, the role of community-based natural resource management with tourism development is highlighted in government policies and supported with legal reforms and new frameworks. The reforms providing a basis for the creation of community conservancies in Namibia were motivated by a combination of different contextual factors. These include the conservation gains witnessed in private ranges in the 1970s and 1980s, following the transfer of authority over wildlife to private landowners. The community-based programmes were also initiated in northwest Namibia in the early 1980 s by a local conservation organisation (Owen-Smith 2010). In addition, there were emerging lessons from international examples to utilise (e.g. Zimbabwe's Communal Areas Management Programmes for Indigenous Resources). As a result, over 54 conservancies have been established, with about $17 \%$ of Namibia's total land area now falling under their jurisdiction (NACSO 2007). While it is true that the rights granted to communities are conditional and fall short of full ownership of wildlife (e.g. the determination of hunting quotas is still largely the responsibility of central government officials (Ngoitiko et al. 2010)), the extent of devolution is relatively robust (Long 2004).

The Ministry of Environment and Tourism (MET) initiated a community-based tourism policy, which 
explores how local communities could benefit from the tourism sector. The policy has strong links to the Namibian community-based natural resource management (CBNRM) programme and communal conservancy system (CCS) (see Long 2004; Saarinen 2010; Suich 2010). The involvement of communities is expected to ensure that the benefits of tourism trickle down to the local level: the level where tourist activities actually take place. However, in addition to public policymakers, tourism regulators (e.g. MET) and various NGOs, the tourism developers and private business environment in Namibia need to recognize the full potential of rural tourism development in order to meet the political promises. Based on the current and somewhat competing versions of national level tourism policies, it is obvious that better integration between tourism, national and regional development aims is urgently needed. Otherwise tourism development actions may serve more the sector and less the people in the future, manifesting contemporary modes of neoliberal governance and political economy in tourism, community and conservation relations.

In this context, currently missing national tourism policy could provide an enabling framework, integrating the tourism sector's development aims to rural and community development needs. Thus, in order to guide the mainstream business growth and develop benefit sharing models between the large scale tourism businesses (contrast to CBT or CBE driven initiatives) and rural communities, a legislative or other regulative framework and coordination are highly needed. This coordination could also assist and empower local communities in "pulling themselves up by their bootstraps" through (rural) tourism development, as Binns and Nell $(1999,2002)$ have observed in South African context. After all, as stated by Scheyvens (2009), we cannot really assume that the mainstream tourism sector has a strong and widely existing ethical commitment to ensure that its businesses really contribute to the rural community development, empowerment and alleviation of poverty. For that, ensuring international and nation-state based structures are still needed.

\section{REFERENCES}

Aref F 2011. Sense of community and participation for tourism development. Life Science Journal 8: 1, 20-25.
Ashley C 2000. The impact of tourism on rural livelihoods: Namibia's experience. Overseas Development Institute, London.

Ashley C \& Haysom G 2008. The development impacts of tourism supply chains: increasing impact on poverty and decreasing our ignorance. In Spenceley A (ed). Responsible tourism: critical issues for conservation and development, 129-156. Earthscan, London.

Ashley C \& Maxwel S 2001. Rethinking rural development. Development Policy Review 19: 4, 395425. http://dx.doi.org/10.1111/1467-7679.00141.

Barnes J \& Novelli M 2008. Trophy hunting and recreational angling in Namibia - an economic, social and environmental comparison. In Lovelock B (ed). Tourism and the consumption of wildlife, hunting, shooting and sport fishing, 155-168. Routledge, London.

Binns T \& Nel E 1999. Beyond the development impasse: the role of local economic development and community self-reliance in rural South Africa. The Journal of Modern African Studies 37: 3, 389-408. http://dx.doi.org/10.1017/S0022278X99003067.

Binns T \& Nel E 2002. Tourism as a local development strategy in South Africa. The Geographical Journal 163: 3, 235-247. http://dx.doi.org/10.1111/1475-4959.00051.

Blackstock K 2005. A critical look at community based tourism. Community Development Journal 40: 1, 39-49.

http://dx.doi.org/10.1093/cdj/bsi005.

Brown F \& Hall D. 2008. Tourism and development in the global south: the issues. Third World Quarterly 29: 5, 839-849. http://dx.doi.org/10.1080/01436590802105967.

Cole S 2006. Information and empowerment. Journal of Sustainable Tourism 14: 6, 139-160. http://dx.doi.org/10.2167/jost607.0.

Dixey L 2008. The unsustainability of community tourism donor projects: lessons from Zambia. In Spenceley A (ed). Responsible tourism: critical issues for conservation and development, 323-342. Earthscan, London.

Florida R 2002. The rise of the creative class and how it's transforming work, leisure and everyday life. Basic Books, New York.

Fuller D, Howard M \& Buultjens J 2006. Indigenous community development and self-employment: with case studies in eco-tourism in North Australia, central Queensland. University Press, Rockhampton.

Gibson C 2010. Geographies of tourism: (un)ethical encounters. Progress in Human Geography 34: 4, 521-527. http://dx.doi.org/10.1177/0309132509348688.

Hall C M 2008. Tourism planning, policies, process and relationships. Prentice Hall, Harlow.

Hirsch F 1978. Social limits to growth. Routledge, London.

Jauch H 2001. Playing for globalization game: the implications of economic liberalization for Namibia. LaRRI, Windhoek. 
Jenkins C 2000. The development of tourism in Namibia. In Dieke P (ed). The political economy of tourism development in Africa, 113-128. Cognizant Communication Corporation, New York.

Jones B \& Weaver C 2009. CBNRM in Namibia: growth, trends, lessons and constraints. In Suich $\mathrm{H}$, Child B \& Spenceley A (eds). Evolution and innovation in wildlife conservation: parks and game ranches to transfrontier conservation areas, 223242. CABI, London.

Jänis J 2009. Tourism development strategies in Namibia: private and community perceptions on the national policy. In Hottola P (ed). Tourism strategies and local responses in southern Africa, 8-26. $\mathrm{CABI}$, Oxon.

Kiss A 2004. Is community-based ecotourism a good use of biodiversity conservation funds? Trends in Ecology and Evolution 19: 5, 232-237. http://dx.doi.org/10.1016/j.tree.2004.03.01.

Lapeyre R 2010. Community-based tourism as a sustainable solution to maximize impacts locally: the Tsiseb conservancy case, Namibia. Development Southern Africa 27: 5, 757-772. http://dx.doi.org/10.1080/0376835X.2010.522837.

Lapeyre R 2011. Governance structures and the distribution of tourism income in Namibia communal lands: a new institutional framework. Journal of Economic and Social Geography, 102: 3, 302-315. http://dx.doi.org/10.1111/j.1467-9663.2011.00665.x.

Libanda B \& Blignaut J 2007. Tourism's local benefits for Namibia's community-based natural resource management areas. International Journal for ECOlogical Economics and Statistics 10: W08, 249-259.

Long S 2004. Livelihoods and CBNRM in Namibia: the findings of the WILD project. Directorate of Environmental Affairs, MET, Windhoek.

Marope M 2005. Namibia human capital and knowledge development for economic growth with equity. Africa region human development working paper series. The World Bank, New York.

Massyn PJ 2007. Communal land reform and tourism investment in Namibia's communal areas: a question of unfinished business? Development Southern Africa 24: 3, 381-392. http://dx.doi.org/10.1080/03768350701445384.

[MET] Ministry of Environment and Tourism 2007. National tourism policy for Namibia. Draft (September 2007). Government of Namibia, Windhoek.

Murphy P 2004. Strategic management for tourism communities: bridging the gaps. Channel View, London.

NACSO 2007. Namibia's communal conservancies: a review of progress and challenges. Namibia Association of CBNRM Support Organization, Windhoek.

Naher E 2006. The contribution of community-based tourism to regional rural development: the case of Namibia. Unpublished MA Thesis. University of Bayreuth, Bayreuth.

[NTB] Namibia Tourism Board 2012. Namibia tourism satellite account. Namibia Tourism Board, Windhoek.
Ndlovu J, Nyakunu E \& Kavita E 2011. Re-defining the rural space in the Kuiseb Delta: examining the potential tourism benefits for the Topnaars in $\mathrm{Na}$ mibia. Journal of Hospitality Management 2: 4, 48-56. http://dx.doi.org/10.5897/JHMT11.028.

Ngoitiko M, Sinandei M, Meitaya P \& Nelson F 2010. Pastoral activities: negotiating power imbalances in the Tanzanian Serengeti. In Nelson F (ed). Community rights, conservation and contested land: the politics of natural resources governance in Africa, 269-289. Earthscan, London.

Novelli M \& Gebhardt K 2007. Community-based tourism in Namibia: reality show or window dressing? Current Issues in Tourism 10: 5, 443-479.

http://dx.doi.org/10.1080/14616688.2013.806583.

Owen-Smith G 2010. An arid Eden: a personal account of conservation in the Kaokoveld. Ball Publishers, Johannesburg.

Rapley J 2002. Understanding development theory and practice in Third World. Boulder/CO, New York.

Rogerson CM 2006. Pro-poor local economic development in South Africa: the role of pro-poor tourism. Local Environment 11: 1, 37-60.

http://dx.doi.org/10.1080/13549830500396149

Saarinen J 2010. Local tourism awareness: community views in Katutura and King Nehale conservancy, Namibia. Development Southern Africa 27: 5, 713-724. http://dx.doi.org/10.1080/0376835X.2010.522833.

Saarinen J 2011. Tourism, indigenous people and the challenge of development: the representations of Ovahimbas in tourism promotion and community perceptions towards tourism. Tourism Analysis 16: 1, 31-42. http://dx.doi.org/10.3727/10835421 1 X12988225900009.

Saarinen J \& Niskala M 2009. Selling places and construction local cultures in tourism: the role of the Ovahimba in Namibian tourism promotion. In Hottola P (ed). Tourism strategies and local responses in southern Africa, 61-72. CABI, Oxon.

Saarinen J \& Rogerson CM 2014. Tourism and the millennium development goals: perspectives beyond 2015. Tourism Geographies 16: 1, 23-30. http://dx.doi.org/10.1080/14616688.2013.851269.

Saarinen J, Becker F, Manwa H \& Wilson D 2009. Introduction: call for sustainability. In Saarinen J, Becker F, Manwa H \& Wilson D (eds). Sustainable tourism in Southern Africa: local communities and natural resources in transition, 3-19. Channel View, Bristol.

Scheyvens R 2002. Tourism for development: empowering communities. Prentice Hall, Harlow.

Scheyvens R 2009. Pro-poor tourism: is there value beyond the rhetoric? Tourism Recreation Research 34: 2, 191-196.

http://dx.doi.org/10.1080/02508281.2009.11081590.

Scheyvens R 2011. Tourism and poverty. Routledge, London.

Scholz S 2009. Tourism, nature conservation and environmental legislation in Namibia. In Saarinen J, Becker F, Manwa H \& Wilson D (eds). Sustainable 
tourism in southern Africa: local communities and natural resources in transition, 150-168. Channel View Publications, Bristol.

Simpson M 2007. An integrated approach to assess the impacts of tourism on community development and sustainable livelihoods. Community Development 44: 2, 186-208.

http://dx.doi.org/10.1093/cdj/bsm048.

Sinclair M 1998. Tourism and economic development. Journal of Development Studies 34: 5, 1-51. http://dx.doi.org/10.1080/00220389808422535.

Sinclair M \& Stabler M 1997. The economics of tourism. Routledge, London.

Suich H 2010. The livelihood impacts of the Namibian community based natural resource management programme: a meta-synthesis. Environmental Conservation 37: 1, 45-53. http://dx.doi.org/10.1017/S0376892910000202.

Tosun C 2000. Limits to community participation in the tourism development process in developing countries. Tourism Management 21: 3, 413-633. http://dx.doi.org/10.1177/1096348004268196.

Tribe $J 2006$. The truth about tourism. Annals of Tourism Research 33: 2, 360-381. http://dx.doi.org/10.1016/j.annals.2005.11.001.

[UNCTAD] United Nations Conference on Trade and Development 2010. The contribution of tourism to trade and development. Geneva, 3-7 May 2010.

Weaver D \& Elliot K 1996. Spatial patterns and problems in contemporary Namibian tourism. The Geographical Journal 162: 2, 205-217. http://dx.doi.org/10.2307/3059877.

[WEF] World Economic Forum 2001. The African competitiveness report. Oxford University Press, New York.

[WTTC] World Travel and Tourism Council 2007. Namibia: the impact of travel and tourism on jobs and the economy. World Travel and Tourism Council (WTTC) Booklet, Windhoek. 